\title{
The strategy of developping group guidance model based on experience as a preventive effort LGBT behavior in student
}

\author{
Neviyarni S. \\ Universitas Negeri Padang, Padang - Indonesia, (neviyarni@konselor.org)
}

\begin{abstract}
This article aims to present the strategy of developing an experience-based group guidance model as an effort to prevent LGBT behavior on students. Specifically, it aims to discuss: (1) practical needs and strategic needs that include student needs, counselor needs, achievement needs, institutional needs and situational needs; (2) the profile of student needs for experience-based group guidance as an effort to prevent LGBT behavior on students 3) based on the needs analysis, a need map is made to determine the service materials to be provided (4) the development of the guidance model of the group as an effort to prevent LGBT behavior on the students and (5) model validation through the implementation of experience-based group counseling model as an effort to prevent LGBT behavior on college student. With this strategy is expected to be developed model of experience-based group guidance as an effort to prevent LGBT behavior on students.
\end{abstract}

Keywords: Experience-based group guidance, prevention,LGBT behavior.

\section{Introduction}

Today the phenomenon of Lesbian, Gay, Bisexual, and Transgender (LGBT) is so busy discussed among the people of Indonesia. It has been suggested that many are offered or promoted on various social media with propaganda for LGBT recruitment. It has entered into places such as schools, college campuses, swimming pools, tourist destinations, and crowded places frequented by the public (Harahap, 2016). Special magazines for LGBT have also been published to meet the information and communication needs of its adherents (Juditha, 2014).

Among the issues discussed in Indonesian society lately is the offer of certain groups for the acceptance of Lesbian, Gay, Bisexual, and Transgender (LGBT) in the community. The number of LGBT promotions or advertisements in social media is due to social media is very difficult to detect by law enforcement, safe and the number of people who use social media making it easier for them to find targets to be recruited. The LGBT group also tries to enter every level of social, economic, and educational status. The fact that the majority of LGBT members are students proves that LGBT has entered the university environment (Harahap, 2016, Prasetyo\&Amri, 2017).

Schools and colleges usually create a conducive and safe learning environment for learners, so that they can learn well in achieving their educational goals. LGBT students often feel the need to deal 
with harassment, intimidation, and discrimination in their environment. LGBT youth often suffer verbal, non-verbal abuse that may escalate into physical intimidation such as pushing, punching, kicking, so it often leads to suicide attempts (Munoz-Plaza, Quinn, Sandra, \& Rounds, 2002; Bontempo\&D'Augelli, 2002; Toomey, et al., 2010). LGBT goods such as cars, motorcycles, clothes, shoes, books are often tampered with, this may result in the student dropping out of college (drop out). Harassment to LGBT youth will affect its academic activities. Some LGBT youth experience difficulty in concentrating, unable to focus on learning, emotionally or physically he distance himself from being on campus. LGBT people feel unsafe and comfortable to be on campus, so he skipped, and away from campus activities. Physically, psychologically, academically and religiously, LGBT is not good for its adherents.

The more openly LGBT people today are not free from the international recognition of LGBT. This is evidenced by the existence of magazines created specifically for the LGBT already spread in several countries (Juditha, 2014). Many foreign countries have legalized same-sex marriage, even the United States openly expressed support for the human rights of LGBT people (Winurini, 2016). A large number of people who are already receiving LGBT at the moment is important for us to shape the negative attitudes of children, adolescents, adults, and parents towards LGBT behavior. It is expected that they refuse if there is an invitation or seduction to behave LGBT. The surrounding environment, culture, way of association, religion, and residence are factors that influence the students' perception related to LGBT (Suherry, Mandala, Mustika, Bastiar, \&Novalino, 2016; Wati\&Subandi, 2017).

LGBT behavior should be prevented, as this is against the norms prevailing in Indonesian society. The behavior of the LGBT community is contrary to religious norms, customary norms, social norms, and scientific norms that need to be obeyed. If viewed from the point of view of the teachings of Islam, LGBT considered as a deviant behavior and very dangerous for humanity. Islam has very clearly prohibited LGBT, even in the Qur'an there are already rules related to LGBT. Not only is it opposed by Islamic groups, such as FPI, MUI (Islamic Scholars Society), etc. LGBT is also opposed by Christian religious communities and so because LGBT behavior is considered a sinful act for all religions in Indonesia (Juditha, 2014 ). LGBT also violates the prevailing norms in Indonesia that refer to Pancasila, especially in the first Sila which shows divine values and in accordance with the divine principles that must be adhered to (Winurini, 2016).

LGBT behavior on students should be prevented in various ways, so as not to harm the individual and the environment and the people around him. One of the efforts that can be done is by improving students' understanding of their religion, experience, health, and sexual identity, how students view themselves (Allen \& Jr., 2004, Dacholfany\&Khoirurrijal, 2016; Harper et al., 2013; Oba \& Pope, 2013). By increasing students' understanding of their sexual identity, it is expected to prevent students from LGBT, such as by applying the "portfolio-based learning" or "portfolio-based learning" and "portfolioassists assessment" models (Sulaiman, Hasan, \&Maksum, 2017), religious psychotherapy approach (Pasilaputra, 2016).

In the guidance and counseling one of the efforts that can be done to improve the understanding of students, especially related to their sexual identity by providing experience-based group guidance services as an effort to prevent LGBT behavior on students. Group guidance is the counselor's effort to help the various problems faced by clients such as education, work, personal, and social issues, utilizing group dynamics. Counselors can conduct career exploration groups, self esteem groups, groups for children from divorced families, violate children's groups, groups to practice interpersonal skills or personal development groups (Corey, 2010). The guidance of experience-based groups is more likely to be behavioral than to violate personal rules and development.

At this time group guidance is widely used counselor for the intervention of handling problems in various life background. The group's main focus is to help group members make mental changes, ways of thinking, feeling, behaving and behaving. In this case, counselors can play a role in 
facilitating interaction between group members, helping group members learn from other members, helping members set personal goals, encouraging group members to transfer their thoughts into concrete behavioral plans that will be done outside the group, helping group members focus, and identify group members' expectations for exploration (Astuti, 2016).

Corey (2008) states that the purpose of group guidance so that group members can learn from each other and share the following things: to trust oneself and others, to raise awareness and selfknowledge to develop the impression of a unique identity; recognize the needs of members in general and the problem; and develop an impression of relevance; helping members learn to create meaningful and intimate relationships with others; find resources within the members of the group and society as a way of directing their attention; enhancing self-acceptance, self-confidence, respect for oneself, and achieving a new understanding of self and others; learn to express emotions in a healthy way, and constructive ways, develop attention and affection towards others; find alternatives to address development issues and resolve conflicts; increase self-direction, interdependence, and responsibility to self and others; realizing self-choice and making more comprehensive decisions; make specific plans to change the behavior and commitment to implement the plans made; learn more effective social skills; learning to be more sensitive to the needs and feelings of others; learning to face the challenges of others with care, concern, honesty, and direction; clarify the value of oneself and decide how to modify the values they have. These objectives can be achieved by implementing experience-based group guidance according to the needs of group members. The purpose of writing this article is to examine the development strategy of experience-based group guidance model as an effort to prevent LGBT behavior on students.

\section{Discussion}

Lesbian, Gay, Bisexual, and Transgender (LGBT) are deviant behaviors that can be very bad for the perpetrators, for example in Canada from 1985-2011 54.7\% of 69,856 HIV positive homosexual men (Anwar \&Wahyuni, 2017). Badrunnisa, chairman of PPKB Kota Banda Aceh, explained that social media is a favorite place for LGBT groups looking for new members. Because in addition to difficult to detect by law enforcement, safe and many targets that can be invited. The LGBT phenomenon can be involved in various layers of society. The surprising fact is that the majority of LGBT members are students and the rest of the school students and other professions (Prasetyo\&Amri, 2017).

LGBT actors have a higher health problem than those who are normal in sexual behavior (Russell, Franz, \& Driscoll, 2001; Russell \& Joiner, 2001; Bontempo\&D'Augelli, 2002; Russell, 2006; Ziyadeh et al., 2007). In fact, LGBT adolescents experience extra stress beyond those encountered by heterosexuals due to their deviant sexual behavior (Kosciw et al., 2012). The results of a national survey of school climate, for example, show that most LGBT students $(81.9 \%)$ reported being verbally abused at school, sexually harassed $(64.4 \%)$ and physically abused $(44.7 \%)$ by peers in school because of their wrong sexual orientation (Kosciw et al., 2012).

One effort that can be done in preventing LGBT behavior on students is by providing experiencebased group guidance services. The experience-based group guidance model begins by presenting the student experience and then the experience is investigated by inquiry approach. An inquiry-based approach is an approach based on the scientific method (Oktarisa, 2016). Learning from experience has the following four stages: Concrete Experience, Reflective Observation, conceptualizing the results of the Abstract Conceptualization, testing the concepts that have been made to make decisions (Active Experimentation) (Kolb, 2013 ). Surya and Natawidjaja (in Rusmana, 2009) describe several benefits of group counseling services, such as (1) more effective and efficient group guidance, (2) able 
to utilize one's influence, (3) mutual sharing experience members so as to influence the change in the behavior of the individual.

Experience-based group guidance services, in counselors can play a role to facilitate interaction between group members, help group members learn from other members, help members set personal goals, encourage group members to transfer their thoughts into concrete behavioral plans that will be done outside the group, help group members focus, and identify group members' expectations for exploration (Astuti, 2016).

The guidance of experience-based groups as an effort to prevent LGBT behavior on students through the early stages/formation, transition, activities, inference, and termination (Prayitno, 2012). This group guidance is carried out according to the needs of group members by utilizing the experiences of group members. Learning from experience in accordance with the concepts found by Kolb (2013) has the following four stages: Concrete Experience, Reflective Observation, Conceptualizing Abstract Conceptualization, Examining the Concept Created to make decisions (Active Experimentation). At the stage of formation, group members are informed that in this group guidance activities will be used experience learning approach and implemented at the stage of activity.

The model of experience-based group guidance as an effort to prevent LGBT behavior on students is built based on practical needs as well as strategic needs that include student needs, counselor needs, achievement needs, institutional needs and situational needs. Required profile needs of students for experience-based group guidance as an effort to prevent LGBT behavior on students to build models. The profile of the student's needs is based on student needs data collected with the application of instrumentation services. Based on the results of the application of instrumentation services obtained by the data set to analyze the needs of students. Having known the needs of students than can be made a map of the need to determine the material services to be discussed in the guidance of experience-based group.

Based on the service materials that will be discussed in group guidance according to the needs of the students, the model of experience-based guidance group developed as an effort to prevent LGBT behavior on the students. The model of experience-based group counseling as an effort to prevent LGBT behavior on students consists of: rational, philosophical and understanding foundations, vision, mission, objectives, implementation stages, personnel, functions, facilities, service content, success criteria, expected counselor skills qualifications, system, the conditions necessary to transfer the group guidance model to other groups.

The last validation of the model through the implementation of experience-based group guidance model as an effort to prevent LGBT behavior on students. With this strategy is expected to be developed a model of experience-based group guidance as an effort to prevent LGBT behavior on students.

The model of experience-based group guidance as an effort to prevent LGBT behavior on students is built based on practical needs as well as strategic needs that include student needs, counselor needs, achievement needs, institutional needs and situational needs.

\section{Conclusion}

Based on the previous discussion, LGBT behavior is very disturbing social life in the community. students as academic people are expected to be able to resist if there is an invitation or seduction that leads to LGBT behavior due to the influence of the surrounding environment, culture, how to get along, religion and residence are the factors that influence student perception related to LGBT. LGBT is against the prevailing norms and can cause negative impacts on the lives of individuals and their 
environment. One possible effort to prevent LGBT behavior on students is to provide counseling and guidance services, one of which is experience-based group guidance where group members can share their experiences with LGBT at the stage of the activity. So that each member of the group can benefit himself.

\section{References}

Allen, R., \& Jr, S. (2004). Understanding Gay Identity Development Within the College Environment, 45(2), 185-206.

Astuti, Y. K. (2016). Pembelajaran Berbasis Pengalaman (Experiental Learning) untuk Meningkatkan Keterampilan Berfikir Kritis dan Aktivitas Mahasiswa, 3(3), 148-152.

Bontempo, D., \& D'Augelli, A. (2002). Effects of at-School Victimization and Sexual Orientation on Lesbian, Gay, or Bisexual Youths' Health Risk Behavior. Journal of Adolescent Health. Vol. 30 (5):364-374.

Corey, G. (2010). Theories and Practice of Group Counseling (8th Edition). California: Brooks/Cole.

Dacholfany, I., \& Khoirurrijal. (2016). Dampak Lgbt dan Antisipasinya di Masyarakat. Jurnal Nizham, 5(1). Retrieved from http://repository.ummetro.ac.id/files/dosen/f893aa81c705960fc6121c08f7204b50.pdf

Harahap, R. D. K. A. (2016). LGBT Di Indonesia: Perspektif Hukum Islam, Ham, Psikologi dan Pendekatan Maṣlaḥah. Jurnal AL-AHKAN, 26(2), 223-248.

Harper, A., Martinez, M., Brace, A., Crethar, H. C., Loos, B., Harper, B., ... Lambert, S. (2013). Association for Lesbian, Gay, Bisexual, and Transgender Issues in Counseling Competencies for Counseling with Lesbian, Gay, Bisexual, Queer, Questioning, Intersex, and Ally Individuals. Journal of LGBT Issues in Counseling, 7(1), 2-43. https://doi.org/10.1080/15538605.2013.755444

Juditha, C. (2014). Realitas Lesbian, Gay, Biseksual, dan Transgender (LGBT) dalam Majalah. Jurnal Komunikasi Universitas Tarumanagara, VI(3), 22-30.

Kolb, D. (2013). Kolb's Learning Styles. Retrieved from https://www.businessballs.com/selfawareness/kolbs-learning-styles-64/

Kosciw, J. G., Greytak, E. A., Bartkiewicz, M. J., Boesen, M. J., \& Palmer, N. A. (2012). The 2011 National School Climate Survey. New York, NY: GLSEN.

Munoz-Plaza, C., Quinn, S. C. (Sandra C., \& Rounds, K. A. (2002). Lesbian, Gay , Bisexual and Transgender Students: Perceived Social Support in the High School Environment Transgender Students : The High School Journal, 85(4), 52-63. https://doi.org/10.1353/hsj.2002.0011

Oba, Y., \& Pope, M. (2013). Counseling and Advocacy with LGBT International Students. Journal of LGBT Issues in Counseling, 7(2), 185-193. https://doi.org/10.1080/15538605.2013.785468

Oktarisa, Y. 2016. Penerapan Model Pembelajaran Berbasis Pengalaman Berbantuan Multimedia untuk Meningkatkan Penguasaan Konsep dan Kompetensi Sains Siswa. Jurnal Gravity. Vol. 2 (1):45-58.

Pasilaputra, D. (2016). Pendekatan Psychotherapy Agama Dalam Menanggulangi Perilaku Menyimpang (LGBT). JURNAL EDUCATIVE: Journal of Educational Studies, 1(2).

Prasetyo, D. D., \& Amri, A. (2017). Peranan UP3AI1) Unsyiah Mengantisipasi Pengaruh Pemberitaan LGBT di Media Online Terhadap Mahasiswa. Jurnal Ilmiah Mahasiswa FISIP Unsyiah, 2(3), 1-12.

Prayitno. 2012. Seri Layanan Konseling. Padang: UNP Press.

Rusmana, N. 2009. Bimbingan dan Konseling Kelompok di Sekolah (Metode, Teknik dan Aplikasi). Bandung: Rizqi Press.

Russell, S. T. (2006). Substance Use and Abuse and Mental Health Among Sexual-Minority Youths: Evidence from Add Health. In A. M. Omoto \& H. S. Kurtzman (Eds.), Sexual Orientation and Mental Health: Examining Identity and Development in Lesbian, Gay, and Bisexual People (pp. 13-35). Washington, DC: American Psychological Association. 
Russell, S. T., \& Joyner, K. (2001). Adolescent Sexual Orientation and Suicide Risk: Evidence from a National Study. American Journal of Public Health. Vol. 91 (8):1276-1281.

Russell, S. T., Franz, B. T., \& Driscoll, A. K. (2001). Same-Sex Romantic Attraction and Experiences of Violence in Adolescence. American Journal of Public Health. Vol. 91 (6):903-906.

Suherry, Mandala, E., Mustika, D., Bastiar, R., \& Novalino, D. (2016). Lesbian, gay, biseksual, dan transgender (lgbt) dalamperspektif masyarakat dan agama. Jurnal Aristo, 4(2), 89-99.

Sulaiman, Hasan, H., \& Maksum, H. (2017). Model Project Citizen untuk Mengatasi Gaya Hidup Lesbian, Gay, Biseksual, dan Trangender (LGBT). Seminar Nasional II USM 2017 Eksplorasi Kekayaan Maritim Aceh di Era Globalisasi dalam Mewujudkan Indonesia sebagai Poros Maritim Dunia (Vol. 1, pp. 448-454).

Toomey, R. B., Ryan, C., Diaz, R. M., Card, N. A., \& Russell, S. T. (2010). Gender-Nonconforming Lesbian, Gay, Bisexual and Transgender Youth: School Victimization and Youth Adult Psychosocial Adjustment. Developmental Psychology. Vol. 46 (6):1580-1589.

Wati, W., \& Subandi. (2017). Gambaran Persepsi Remaja Terhadap Perilaku Lesbian, Gay, Biseksual dan Transgender (LGBT) di SMAN 1 Tamansari Kabupaten Bogor. Jurnal Riset Kesehatan, 9(2), $19-25$.

Winurini, S. (2016). Memaknai Perilaku LGBT di Indonesia (Tinjauan Psikologi Abnormal). Jurnal Pusat Penelitian Badan Keahlian DPR RI, VIII(5), 9-12.

Ziyadeh, N. J., Prokop, L. A., Fisher, L. B., Rosario, M., Field, A. E., Camargo, C. A., \& Austin, S. B. (2007). Sexual Orientation, Gender, and Alcohol Use in a Cohort Study of u.s. Adolescent Girls and Boys. Drug and Alcohol Dependence. Vol. 87 (2-3):119-130. 